\title{
Towards a global justice vision for climate law in a time of 'unreason'
}

\author{
Rosemary Lyster* \\ Professor of Climate and Environmental Law, Sydney Law School, The University of Sydney; Director, \\ Australian Centre for Climate and Environmental Law, Australia
}

It seems that there are parallel realities when it comes to the threats that global climate change poses, not only to the sustainable development agenda, but to the survival of the planet. On the one hand, climate science has become ever more compelling. Yet at the international negotiations, under the United Nations Framework Convention on Climate Change (UNFCCC), countries have failed to make the commitments necessary to achieve their stated objective of keeping the rise in global temperatures below $2^{\circ} \mathrm{C}$ above preindustrial levels. The Rio+20 United Nations Conference on Environment and Development concluded in June 2012 with 'The Future We Want' as the principal outcome of the Conference. Not surprisingly, 'The Future We Want' makes frequent reference to global climate change as being a key disruptor of sustainable development and states 'that the scale and gravity of the negative impacts of climate change affect all countries and undermine the ability of all countries, in particular, developing countries, to achieve sustainable development and the Millennium Development Goals and threaten the viability and survival of nations'. This article seeks to articulate the reasoning upon which the international community should base its responses to climate change. It will argue that there is an urgent need for a process of impartial public reasoning and discussion on the issue of climate change to emerge, so as to limit the imperatives of national interest and move towards a global justice approach. In so doing it will rely upon Amartya Sen's The Idea of Justice and Stephen Gardiner's A Perfect Moral Storm: Climate Change, Intergenerational Ethics and the Problem of Moral Corruption. In developing this thesis, the author will of necessity refer to a contrary view offered by Eric Posner and David Weisbach in Climate Change Justice where the authors allow national, or local, preferences to dictate the parameters of a climate change treaty.

Keywords: climate change justice, climate science, post-2012 framework, Australia, United States (US), European Union, South Korea, China

\section{INTRODUCTION}

The Rio+20 United Nations Conference on Environment and Development concluded in June 2012 with 'The Future We Want' ${ }^{1}$ as the principal outcome of the Conference. Shortly before that, in May 2012, the Conference of the Parties to the United Nations

* Rosemary would like to acknowledge the contribution of her research assistant, Chris Cain, whose tireless work in sourcing many of the materials has proved invaluable.

1. A/CONF.216/L.1 available at <http://daccess-dds-ny.un.org/doc/UNDOC/GEN/N12/381/ 64/PDF/N1238164.pdf?OpenElement> accessed 25 June 2012. 
Framework Convention on Climate Change (UNFCCC), also serving as the Meeting of the Parties to the Kyoto Protocol, met in Bonn to continue their negotiations prior to the Eighteenth Conference of the Parties (COP 18) in December 2012. It should come as no surprise that 'The Future We Want' makes frequent reference to global climate change as a key disruptor of sustainable development. In the document, the international community identifies eradicating poverty as being 'the greatest global challenge facing the world today and an indispensable requirement for sustainable development' which must be addressed 'as a matter of urgency'. ${ }^{2}$ However it acknowledges that 'climate change is a cross-cutting and persistent crisis' and expresses its concern 'that the scale and gravity of the negative impacts of climate change affect all countries and undermine the ability of all countries, in particular, developing countries, to achieve sustainable development and the Millennium Development Goals and threaten the viability and survival of nations'. ${ }^{3}$ The Parties 'underscore that combating climate change requires urgent and ambitious action' ${ }^{4}$ and notes with 'grave concern the significant gap between the aggregate effect of mitigation pledges by parties in terms of global annual emissions of greenhouse gases by 2020 and aggregate emission pathways consistent with having a likely chance of holding the increase in global average temperature below $2^{\circ} \mathrm{C}$, or $1.5^{\circ} \mathrm{C}$ above pre-industrial levels' ${ }^{5}$ Indeed, the Parties' best efforts to date, in terms of their voluntary Copenhagen commitments, are likely to result in a warming trajectory of $3.2^{\circ} \mathrm{C} .{ }^{6}$

Yet it seems that there are parallel realities when it comes to the threats that global climate change poses, not only to the sustainable development agenda, but to the survival of the planet. On the one hand, climate science has become ever more compelling. Yet at the international negotiations, under the UNFCCC, ${ }^{7}$ countries have failed to make the commitments necessary to achieve their stated objective of keeping the rise in global temperatures below $2^{\circ} \mathrm{C}$ above pre-industrial levels. The US has not yet ratified the Kyoto Protocol and Canada withdrew from it in $2011 .^{8}$ Meanwhile, the major developing country emitters such as China, India and Brazil, relying on the common but differentiated principle, ${ }^{9}$ insist that developed economies should take on new, significant and legally binding emissions reductions targets while developing economies are allowed to continue along their development paths.

Is there any way out of this? How might the international deadlocks be broken and domestic governments be persuaded to think afresh about a looming global crisis? The author will rely on the work of two eminent philosophers to suggest that what is needed is a global justice vision for climate law during this time of 'unreason'. The works are Amartya Sen's The Idea of Justice ${ }^{10}$ and Stephen Gardiner's A Perfect

2. Ibid., Art. 2.

3. Ibid., Art. 25.

4. Idem.

5. Ibid., Art. 121.

6. See J Rogel, 'Copenhagen Accord Pledges are Paltry' (2010) 464 Nature $1126<$ http:// www.nature.com/nature/journal/v464/n7292/full/4641126a.html> accessed 19 June 2011.

7. Available at <http://unfccc.int/files/essential_background/background_publications_ htmlpdf/application/pdf/conveng.pdf> accessed 29 June 2012.

8. Canada has withdrawn from the Kyoto Protocol rather than pay the expected $\$ 13.6$ billion penalty for being in non-compliance with its Kyoto target. It has also cited non-ratification by the US and China as legitimizing its position.

9. This principle is found in Art. 3.1 of the UNFCCC, above $\mathrm{n} 7$.

10. A Sen, The Idea of Justice (Penguin Books, London 2009). 
Moral Storm: Climate Change, Intergenerational Ethics and the Problem of Moral Corruption. ${ }^{11}$ Sen encourages us, when considering questions of justice, to engage in a process of public reasoning and discussion and to focus on the 'actual lives' of those most likely to suffer. We need to broaden the informational basis of our evaluations, free from vested interests. He tells us that the prevalence and resilience of 'unreason' must be confronted by better reasoning. Meanwhile, Gardiner says we need to think clearly and to protect ourselves against weak or deceptive arguments that permit us to 'pass the climate change buck' to the next generation. Such arguments corrupt the very terms of the debate, moral and otherwise and strike at people's ability to understand what is going wrong in moral terms.

This article seeks to articulate the reasoning upon which the international community should base its responses to climate change. It will argue that there is an urgent need for a process of impartial public reasoning and discussion on the issue of climate change to emerge, so as to limit the imperatives of national interest and move towards a global justice approach. The truth is that there is no way for any jurisdiction to avoid the costs of climate change. Even if some economies attempt to shy away from the costs of mitigation, none will escape paying the adaptation and disaster response costs, particularly for developing countries which are most vulnerable.

In developing this thesis, the author will of necessity refer to a contrary view offered by Posner and Weisbach in Climate Change Justice ${ }^{12}$ where the authors allow national, or local, preferences to dictate the parameters of a climate change treaty. The author will not review the work extensively, as this has been done by others. ${ }^{13}$ As has been stated elsewhere, ${ }^{14}$ Posner and Weisbach, to their credit, do genuinely desire a treaty that will address the phenomenon of climate change and they are neither climate denialists nor sceptics. They also illustrate a clear interest in global justice and a concern for the world's poor. Yet the author will agree that this work is 'yet another disheartening book on climate change'. ${ }^{15}$ More than this, the author will argue that, however unwittingly, the type of reasoning provided by Posner and Weisbach is the type against which Gardiner warns us to protect ourselves lest aspects of it corrupt the terms of the moral debate about climate change.

In this way, the article adds to the climate justice literature by confronting one view in the climate change literature, provided by Posner and Weisbach, with another dominant view in the more general debate on international justice provided by Sen, and adapted by the author. ${ }^{16}$ These competing philosophical approaches may also clarify and explain the current political deadlock in the post-2012 debate.

11. SM Gardiner, A Perfect Moral Storm: The Ethical Tragedy of Climate Change (Oxford University Press, Oxford 2011).

12. EA Posner and D Weisbach, Climate Change Justice (Princeton University Press, Princeton, NJ 2010).

13. For the most comprehensive review of this work see Daniel A Farber, 'Climate Justice' available at $<$ http://ssrn.com/abstract=1883186> accessed 28 September 2011.

14. See D Schlosberg's review of the book in (2010) 1(3) Climate Law 454-7.

15. Ibid.

16. While Sen's work has been relied upon to develop a capabilities approach to climate change justice for humans and non-humans (see for example D Schlosberg, 'Climate Justice Beyond Equity: The Flourishing of Human and Non-Human Communities', APSA 2009 Toronto Meeting Paper available at <http://papers.ssrn.com/sol3/papers.cfm?abstract_id=1449681> accessed 28 September 2011), it has prior to this article not been relied upon to call for a public reasoning approach that would confront the 'unreason' being witnessed at the international and domestic levels of climate regulation. 
The article is organized into discrete but interrelated parts as follows: Part 2 below deals with climate science as a tool for confronting 'unreason'; Part 3 explains how climate scepticism exacerbates 'unreason' and facilitates moral corruption; Part 4 discusses the latest IPCC report on vulnerability and climate disasters further to invoke Sen's call for an impartial reasoning process; Part 5 suggests a way forward towards a global justice vision for climate change and away from parochial vested interests; Part 6 counters a competing law and economics view of climate justice; while Part 7 concludes by demonstrating that although some progress has been made on a post-2012 framework, 'unreason' and 'positional illusion' continue to undermine the international negotiations under the UNFCCC.

\section{CLIMATE SCIENCE CONFRONTS 'UNREASON'}

Central to an impartial scrutiny of issues of climate justice is a sound understanding of climate science and of the expected impacts of climate change on humanity and the planet. This understanding contributes to better reasoning on climate change in the age of 'unreason'. Climate scientists are currently struggling to maintain their credibility in an environment where the smallest details of their research are deconstructed and their research is criticized, not in an effort to search for truth, but in an effort to discredit both their results and the authors of climate research. A clear example of this is the 'Climategate' scandal where, in November 2009, the leaked emails of Phil Jones at the Climate Research Unit, University of East Anglia allegedly showed collusion among climate scientists to hide views contrary to their own; abuse of the peer review process; and a failure to respond to data access requests under the Freedom of Information Act. This incident, discussed more fully below, has done much to damage the consensus that was emerging in society about the dangers of climate change, and the fact that it is human-induced. The risk is that in the process, scientific integrity, independence and transparency are undermined to the point where society is deprived of the insights that climate science could offer. ${ }^{17}$

It seems difficult for scientists to explain, and for the public to accept, that climate science is constructed within the normative structure of science which, beginning with the Enlightenment, has evolved over centuries. The structure of science encompasses the notion of peer-review, which recognizes that science demands openness and transparency of claims and evidence and the commitment 'to an epistemology that embodies a standard of empirical verifiability for certifying knowledge claims'. ${ }^{18}$

While it has been suggested that climate science is a classic example of "postnormal science', ${ }^{19}$ it must be remembered that it is still bounded by the normative structure of science. The features of 'post-normal' climate science which must be confronted include: environmental risks of global proportions in which human beings are

17. W Wagner, 'Introduction' in W Wagner and R Steinzor (eds), Rescuing Science from Politics: Regulation and the Distortion of Scientific Research (Cambridge University Press, Cambridge 2006) 2.

18. S Krimsky, 'Publication Bias, Data Ownership and the Funding Effect in Science: Threats to the Integrity of Biomedical Science' in W Wagner and R Steinzor (eds), Rescuing Science from Politics: Regulation and the Distortion of Scientific Research (Cambridge University Press, Cambridge 2006) 61.

19. See M Hulme, Why We Disagree About Climate Change (Cambridge University Press, Cambridge 2009) 78. 
both perpetrators and victims; and the application of science to public policy issues where 'facts' are uncertain, values are in dispute, stakes are high and decisions are urgent. In this context, science struggles to find new institutional forms and processes to shape knowledge into a usable form. ${ }^{20}$ Climate scientists have had to recognize that the processes by which knowledge is created must be open to public scrutiny and engagement - not just to their community of peers - and that more attention must be paid to establishing and communicating what is known and what is uncertain. ${ }^{21}$

The difficulty with communicating climate science is compounded by the fact that in the context of post-normal science, scientists 'tame' uncertainty by adopting two strategies: by making 'Bayesian' statements of probabilities or beliefs; and by accepting consensus-building as a means to establish scientific knowledge. ${ }^{22}$ In the first instance, it is legitimate for scientists to express their subjective level of confidence about a given outcome. For example, the Intergovernmental Panel on Climate Change (IPCC) expresses its confidence as being 'Virtually certain $>99 \%$ probability of occurrence, Extremely likely $>95 \%$, Very likely $>90 \%$ '.23 Also, it is clear that the IPCC's three Working Groups have accepted consensus building as a structured way of distilling ambiguous, incomplete or contradictory evidence into an overall agreed statement on climate science. ${ }^{24}$ In this context, the boundaries of science have become more porous ${ }^{25}$ and the public may demand adjustments to the ways in which science is governed and its knowledge is policed. ${ }^{26}$

Nevertheless, the 'public' still seems to expect climate science to adjudicate between competing claims to truth and to be able to make robust statements about the likelihood of certain future physical events occurring. ${ }^{27}$ Science still seems to have the authority to make definitive and universal statements about what is and what is not dangerous for people and societies, and ultimately the world. ${ }^{28}$ Likewise, it has seemed that lawmakers and government agencies have nothing but respect for the sanctity and wisdom of the scientific process and its results. Why then do so many scientists who are front and centre of climate science feel "not like anointed and omniscient saviours, but instead like hunted prey' ${ }^{29}$ This is a perilous time for climate scientists as evidenced by 'Climategate' and attacks on the findings of the Intergovernmental Panel on Climate Change. Climate scientists are habitually subjected to vicious and unrelenting email campaigns, including death threats. ${ }^{30}$ They have even

20. Ibid., at 80 .

21. Idem.

22. Ibid., at 84 .

23. See IPCC Fourth Assessment Report: Climate Change 2007: Working Group I: The Physical Science Basis available at <http://www.ipcc.ch/publications_and_data/ar4/wg1/en/ spmsspm-human-and.html> accessed 27 June 2011 at n 6.

24. Hulme, above $\mathrm{n} 19$ at 88 .

25. Ibid., at 92 .

26. Idem.

27. Ibid., at 73 .

28. Ibid., at 74 .

29. Wagner, above $\mathrm{n} 17$ at 1 .

30. See $<$ http://www.canberratimes.com.au/news/local/news/general/climate-of-fear-scientistsface-death-threats/2185089.aspx? src=email\#> accessed 29 June 2011; see also C Hamilton, 'Bullying, Lies and Rise of Right-wing Denial' The Drum, 22 June 2010 available at <http:// www.abc.net.au/unleashed/32912.html> accessed 29 June 2011. 
been threatened by their own universities with criminal prosecution and investigation for research fraud. ${ }^{31}$

\section{CLIMATE SCEPTICISM, 'UNREASON' AND MORAL CORRUPTION}

\subsection{What is the relevance of climate scepticism to moral corruption?}

McGarity, writing in an edited collection entitled Rescuing Science from Politics: Regulation and the Distortion of Scientific Research, which includes the work of scientists, philosophers and lawyers, states that "well-financed and widely publicized attacks on scientific research and the integrity of the scientists undertaking the research ultimately threaten the viability of all scientific research as public respect for the scientific community fades and public support for science dwindles'. ${ }^{32}$ Dwindling public respect for climate science contributes significantly to the state of 'unreason' dominating much of the climate change debate. Yet it is even more serious than this. Such a situation results in the moral corruption of the citizenry, which in itself undermines Sen's hope for a practical reasoning approach to justice, since 'moral reasoning is just as open to misuse as scientific reasoning'. ${ }^{33}$ Stephen Gardiner's thorough treatment of this in A Perfect Moral Storm is apposite. Here Gardiner makes the case that, with climate change, global, intergenerational and theoretical storms converge and exacerbate a distinct problem for ethical action on climate change - the problem of moral corruption. Given the pronounced temporal dispersion of the causes and effects of climate change, current generations may be attracted to weak or deceptive arguments which permit them to give less scrutiny to their inclination to 'pass the buck' to the next generation. Such arguments corrupt the very terms of the debate, moral and otherwise. 'In other words,' says Gardiner, 'the perfect moral storm may work to subvert our understanding of what is at stake'. ${ }^{34}$ Yet 'serious moral agents strive to protect themselves against rationalization, self-deception and moral manipulation' ${ }^{35}$ Consistently with Sen, Gardiner cautions that the potentially catastrophic consequences for the victims of climate change require a special vigilance about our own reasoning. ${ }^{36}$ This is difficult given that moral corruption in its more sophisticated forms seeks to co-opt moral and epistemic values that ought otherwise to be respected. ${ }^{37}$ It strikes at people's ability to understand what is going wrong in moral terms and, for other (usually selfish) ends, it subverts moral discourse itself. ${ }^{38}$

Gardiner provides an insightful and succinct account of the five-pronged 'all-out assault' on the moral demands citizens face. These include: disputing the application of the moral claim (excessive burden, competing special relationships); highlighting the unintended bad consequences of compliance; reducing the magnitude of the

31. See R Lyster, 'Rescuing Climate Science from Politics' <http://www.usyd.edu.au/news/ law/436.html?newsstoryid=5245> accessed 29 June 2011.

32. TO McGarity, 'Defending Clean Science from Dirty Attacks by Special Interests' in Wagner and Steinzor, above n 17 at 25.

33. Sen, above $\mathrm{n} 10$ at 337.

34. Gardiner, above $\mathrm{n} 11$ at 45.

35. Ibid., at 301 .

36. Ibid., at 302 .

37. Idem.

38. Idem. 
moral demand (budget constraints, demanding mutual benefit); undermining the implementation of the duty (discretionary aid, indirect efforts); and breeding resentment on the part of the duty-bearer (recasting oneself as the victim). ${ }^{39}$ These five tactics are easily recognizable to those who have followed the climate change debate over the years. They inform the discussion which follows regarding the tension between Sen's and Posner and Weisbach's approaches to reasoning about justice.

\subsection{Rehabilitating climate science as a building block for public reasoning}

The years 2009-2011 have emerged as crucial years for rehabilitating climate science following the 'Climategate' scandal and attacks on the integrity of the Intergovernmental Panel on Climate Change's (IPCC) Fourth Assessment Report (AR4). 'Climategate' has been subjected to three investigations - by the House of Commons Science and Technology Committee, ${ }^{40}$ by a Science Assessment Panel $^{41}$ and by an Independent Climate Change E-Mails Review. ${ }^{42}$ The House Committee, the Panel and the Review found no evidence of scientific malpractice, with the House Committee concluding that 'there is independent verification, through the use of other methodologies and other sources of data, of the results and conclusions' of the Climatic Research Unit (CRU). ${ }^{43}$ The Committee, Panel and Review found no conspiracy to hide contrary views or of tailoring results to a particular biased agenda. ${ }^{44}$ No evidence of subverting the peer review process was found. CRU and the University were criticized for their culture of resisting disclosure of information to climate sceptics, even though $95 \%$ of the raw data was publicly available. The Committee expressed some sympathy for Jones who knew - or perceived - that the requests were intended to undermine his work. It concluded that climate scientists should make all of their data available online at an early stage. The Review rejected the allegation that CRU had misused the IPCC process.

On 30 August 2011, the InterAcademy Council, an organization of the world's science academies, published its Review of the Processes and Procedures of the IPCC, ${ }^{45}$ which was requested by UN Secretary General Ban Ki-moon in March 2011.

39. Ibid., at 337.

40. See 'The Disclosure of Climate Data from the Climatic Research Unit at the University of East Anglia', HC 387-I, its Eighth Report of Session 2009-10, 31 March 2010 available at <http://www.publications.parliament.uk/pa/cm200910/cmselect/cmsctech/387/387i.pdf> accessed 9 September 2010.

41. See Report of the International Panel set up by the University of East Anglia to examine the research of the Climatic Research Unit available at <http://www.uea.ac.uk/mac/comm/ media/press/CRUstatements/SAP> accessed 9 September 2010.

42. See <http://www.cce-review.org/pdf/FINAL\%20REPORT.pdf > accessed 9 September 2010 .

43. The reference here is to land and sea temperature data collected by the US National Climate Data Center (NDC) and the Goddard Institute of Space Studies (GISS), based at NASA. NDC and GISS each use at least 7200 stations.

44. On a more technical issue, the Review found that controversial tree ring data compiled by CRU to demonstrate temperature change and presented in the 2007 IPCC Report was not misleading, although the Committee and the Review differed about whether a failure in 1999 to disclose the reconstruction and splicing of such data had been misleading.

45. Available at <http://reviewipcc.interacademycouncil.net/report/Climate\%20Change\% 20Assessments, $\% 20$ Review $\% 20$ of $\% 20$ the $\% 20$ Processes $\% 20 \& \% 20$ Procedures $\% 20$ of $\% 20$ the $\%$ 20IPCC.pdf> accessed 9 September 2010. 
The Review was established following concern, widely reported in the media, about the integrity of the scientific conclusions reached by the IPCC's 2007 Fourth Assessment Report. The Review concluded that the IPCC has served society well, but that changes to it process and management structure are needed after 20 years. These include modernizing its management structure; strengthening the review process; characterizing and communicating the uncertainties; developing an effective communications strategy; increasing transparency; clarifying the use of published and non-peer reviewed sources; engaging the best regional experts; expediting approval of the Summary for Policy Makers; reducing the growing burden on the scientific community; and maintaining flexibility of its processes and structures. ${ }^{46}$

\subsubsection{Climate science confirmed and updated}

Between 2009-2011, the climate science presented by the IPCC in its AR4 has been confirmed and indeed updated by many of the world's leading science institutions. ${ }^{47}$ The most recent iteration of the climate science is that by the Australian Climate Commission entitled 'The Critical Decade: Climate Science, Risks and Responses' ${ }^{48}$ Crucially, the Report states that recent observations of changes in the climate system strengthen the conclusions of the IPCC's AR4 that contemporary climate change is real, and that, compared with geological time scales, it is occurring at a rapid rate. The rate of climate change is already discernibly creating significant risks today, and will create more serious risks in the coming decades. ${ }^{49}$

With regard to the causes of climate change, the Report states that ' $[t]$ here is a very large body of internally consistent observations, experiments, analyses, and physical theory that points to the increasing atmospheric concentration of greenhouse gases, with carbon dioxide $\left(\mathrm{CO}_{2}\right)$ the most important, as the ultimate cause for the observed

46. Ibid., Chapter V.

47. See J Hansen, Storms of My Grandchildren: The Truth About The Coming Climate Catastrophe and our Last Chance to Save Humanity (Bloomsbury, London 2009); the 2009 US Environmental Protection Authority 'Endangerment Finding for Greenhouse Gases' available at <http://epa.gov/climatechange/endangerment.html\#findings> accessed 26 June 2012; the US National Oceanic and Atmospheric Administration's Report '2009 The State of the Climate' available at <http://www.ncdc.noaa.gov/bams-state-of-the-climate/2009.php> accessed 15 September 2010; the 2010 Australian National Academy of Science publication 'The Science of Climate Change: Questions and Answers' available at $<$ http://www.science.org. au/reports/climatechange2010.pdf> accessed 15 June 2011; the 2010 US National Academies of Sciences Report 'Advancing the Science of Climate Change' available at $<\mathrm{http} / / /$ dels.nas. edu/Report/Advancing-Science-Climate-Change/12782> accessed 15 June 2011; the 2010 The Royal Society's 'Climate Change: a Summary of the Science' available at $<\mathrm{http} / /$ royalsociety. org/climate-change-summary-of-science> accessed 15 June 2011; the Earth Institute Columbia University's Report 'Climate Change: Addressing the Major Skeptic Arguments' available at <http://www.dbcca.com/dbcca/EN/_media/DBCCAColumbiaSkepticPaper090710.pdf?dbiquery= null:Climat\%20Change:\%20Addressing\%20the\%20Major\%20Skeptic\%20Arguments $>$ accessed 15 September 2010; and 'Climate Scientists Respond to Written Testimony of Monckton before US Select Committee on Energy Independence and Global Warming' available at <http://www. skepticalscience.com/Monckton-response.pdf> accessed 15 June 2011.

48. Available at <http://climatecommission.gov.au/topics/the-critical-decade/> accessed 15 June 2011.

49. Ibid., at 6 . 
warming, ${ }^{50}$ The Report goes on to note that claims that changes in incoming solar radiation can be the cause of the current warming trend lack any credible evidence. Furthermore, the globally coherent warming trend observed since the middle of the twentieth century is not explained by either multi-decadal or century-scale patterns of natural variability, such as the Medieval Warm Period, or shorter term patterns of variability, such as ENSO (El Niño-Southern Oscillation) or the North Atlantic Oscillation. $^{51}$

\section{UNDERSTANDING VULNERABILITY AND CLIMATE DISASTERS AS PART OF SEN'S IMPARTIAL REASONING PROCESS}

The scientific consensus on climate science needs to now be read together with the IPCC's Special Report 'Managing the Risks of Extreme Events and Disasters to Advance Climate Change Adaptation', ${ }^{52}$ released in March 2012. This Report states that there is sufficient evidence to suggest that climate extremes such as heat waves, record high temperatures and, in many regions, heavy precipitation, have changed due to climate change in the past half century. Climate-related disasters can result from climate extremes, or even a series of non-extreme events, which occur in combination with social vulnerabilities and exposure to risks. The impact of these events can be reduced and the resilience of people exposed to extreme events increased if policies to avoid, prepare for, respond to and recover from the risks of disaster are adopted. However, when thresholds or tipping points associated with social and/or natural systems are exceeded, limits to resilience will be reached, posing severe challenges for adaptation.

Not surprisingly, in February 2011, the United Nations General Assembly adopted a Resolution on an International Strategy for Disaster Reduction. ${ }^{53}$ This followed a Report presented to the General Assembly in December 2010 entitled 'Sustainable Development: International Strategy for Disaster Risk Reduction'. ${ }^{4}$ The General Assembly expressed 'its deep concern at the number and scale of natural disasters and their increasing impact in recent years, which have resulted in massive loss of life and long-term negative social, economic and environmental consequences for vulnerable societies throughout the world, ... in particular in developing countries'. Likewise, it expressed 'its deep concern ... at the increasing challenges facing the disaster response and preparedness capacity of Member States and the United Nations system as a result of the combined impacts of ... the global economic and financial crisis, climate change and the food crisis'.

When considering vulnerabilities and exposure to the risks of climate disasters it is worthwhile noting a number of major reports compiled recently by leading agencies

50. Ibid., at 13 .

51. Idem.

52. Available at <http://ipcc-wg2.gov/SREX/> accessed 26 June 2012.

53. A/RES/65/157, 25 February 2011; available at <http://www.preventionweb.net/files/ resolutions/N1052196.pdf> accessed 27 June 2011.

54. Report: 7 December 2011; available at <http://www.preventionweb.net/files/resolutions/ N1067878.pdf> accessed 27 June 2011; see also 'Sustainable Development: Protection of Global Climate for Present and Future Generations of Humankind', A/65/436/Add.4, 2 December 2010 and 'Implementation of the International Strategy for Disaster Reduction: Report of the Secretary-General', A/65/388, 22 September 2010. 
and which focus on existing and future vulnerabilities in terms of cities, food security and disaster risk reduction as a result of climate change.

\subsection{Cities}

UN Habitat's 'Global Report on Human Settlements 2011: Cities and Climate Change', ${ }^{55}$ released in March 2011, sets out some of the possible effects of climate change on the world's cities including the following:

- By 2050, climate change will displace as many as 200 million people.

- By the 2080s sea level rise and its associated impacts will affect five times as many coastal residents as in 1990.

- In coastal North Africa cities, 6-25 million people could be exposed to flooding from sea level rise if temperatures rise between $1-2^{\circ} \mathrm{C}$.

- By 2070, the top ten cities exposed to flooding will be located in developing countries (particularly in China, India and Thailand).

- By 2070, up to 150 million people could be living in a 100-year flood plain with the financial impact rising from US\$3 trillion in 1999 to US $\$ 38$ trillion by this time.

- In Latin America by the 2020s, 12-81 million residents could experience increased water stress and by the 2050 s this could rise to $79-178$ million. ${ }^{56}$

\subsection{Food security}

To meet the expected demand for food in 2050 without significant price increases, and in light of the growing impacts of climate change, amongst others, the world needs to increase food production by $70-100 \% .{ }^{57}$ In December 2010 , the International Food Policy Research Institute released 'Food Security and Climate Change: Challenges to 2050 and Beyond'. ${ }^{58}$ This study considers three scenarios for income and population growth: a baseline scenario (with moderate income and population growth); a pessimistic scenario (with low income growth and high population growth); and an optimistic scenario (with high income growth but low population growth). In the optimistic scenario, income and changed demographics between

55. Available at $<$ http://www.unhabitat.org/content.asp?cid=9599\&catid=7\&typeid=46\&sub MenuId $=0>$ accessed 20 June 2011.

56. Ibid; Press Release for Chapter of the Report entitled 'Risky Cities: The Deadly Collision Between Urbanization and Climate Change' available at <http://www.unhabitat.org/downloads/ docs/GRHS2011/Pr3RiskyCities.pdf> accessed 20 June 2011.

57. See J Pretty et al, 'The Top 100 Questions of Importance to the Future of Global Agriculture' (2010) 8(4) International Journal of Agricultural Sustainability 219 available at $<$ http:// www.julespretty.com/PDF\%20Files/100\%20Questions\%20IJAS\%202010\%20Pretty\%20et\% 20al\%202010.pdf $>$ accessed 20 June 2011 at 220.

58. Available at $<$ http://www.ifpri.org/sites/default/files/publications/ib66.pdf $>$ accessed 20 June 2011. See also 'Climate Smart' Agriculture: Policies, Practices and Financing for Food Security, Adaptation and Mitigation (FAO, Rome 2010) available at <http://www.fao.org/ docrep/013/i1881e/i1881e00.htm> accessed 20 June 2011 and 'CARE International Climate Change Brief Adaptation and Food Security' available at $<$ http://www.careclimatechange.org/ files/CARE_docs/CARE_Food_Security_Brief_2011.pdf> accessed 27 June 2011. 
2010 and 2050 show price increases that range from $10.8 \%$ for rice, with a $53.9 \%$ increase for maize in the pessimistic scenario. The underlying pressures on the world food system are evident even in the unlikely event that perfect mitigation of greenhouse gas emissions is achieved. With climate change, price increases will range from $31.2 \%$ for rice in the optimistic scenario and $100.7 \%$ for maize in the baseline scenario. ${ }^{59}$

These scenarios need to be viewed against the background of the 2008 food-price hike leading to food riots and political change in several countries, as well as the excessive heat and drought in Russia leading to wildfires ${ }^{60}$ and a grain embargo and the unprecedented floods in Pakistan. Food demand will inevitably increase as the world population reaches 9 billion by $2050 .{ }^{61}$ Since food production is critically dependent on local temperatures and precipitation, climate change will only add to these pressures as the capacity for farmers to adapt their practices is questionable. ${ }^{62}$ By 2050, climate change is likely to increase the number of malnourished children in all developing countries by $8.5 \%$ in the optimistic scenario and $10.3 \%$ in the pessimistic scenario. ${ }^{63}$

\subsection{Disaster Risk Reduction scenarios}

The '2011 Global Assessment Report on Disaster Risk Reduction' ${ }^{64}$ indicates that disasters continue to destroy the lives and livelihoods of millions of people. The January 2010 earthquake in Haiti and July 2010 floods in Pakistan highlight the close link between disaster risk and poverty. Meanwhile, the 2011 floods in Australia, the earthquakes in New Zealand and Japan, and the tsunami and nuclear disaster in Japan are a stark reminder that developed countries are also highly exposed, although it is not suggested that earthquakes are an incidence of climate-related disasters. Hundreds of smaller climate variability disasters also caused extensive damage in Benin, Brazil, Colombia, the Philippines and other countries in 2011.

The Report states that mortality risk for all weather-related hazards continues to be concentrated in countries with low GDP or weak governance. Since 1970, populations 'at risk' to exposure from tropical cyclones has tripled while the challenges inherent in

59. IFPRI ibid., at 2.

60. See also J Williams et al, 'Findings and Implications from a Coarse/Scale Global Assessment of Recent Selected Mega-Fires' $5^{\text {th }}$ International Wildland Fire Conference, Sun City, South Africa, 9-13 May 2011; here the authors report on 'mega-fires' which are extraordinary conflagrations unprecedented in the modern era for their deep and long-lasting social, economic and environmental impacts. Global warming is identified as one of the cumulative effects changing wildfire protection in many countries; available at $<\mathrm{http}$ //foris.fao.org/static/pdf/fm/ 5thIWFConference2011.pdf> accessed 19 June 2011.

61. Ibid., at 1 .

62. Ibid., at 2 .

63. Ibid., at 7.

64. Executive Summary available at $<$ http://www.preventionweb.net/english/hyogo/gar/2011/ en/home/executive.html> accessed 19 June 2011. The United Nations International Strategy for Disaster Reduction (UNISDR) secretariat produced this report, in collaboration with many global partners; see also Natural Hazard Unnatural Disasters: The Economics of Effective Prevention (The World Bank and the United Nations, Washington, DC November 2010) available at $<$ http://issuu.com/world.bank.publications/docs/9780821380505> accessed 27 June 2011; see also 'Managing the Risks of Extreme Events and Disasters to Advance Climate Change Adaptation' above n 52 . 
reducing flood risk were evident in the August 2010 Pakistan floods which resulted in 1700 fatalities.

Economic loss associated with floods and cyclones increased in all regions with the Pakistan flood alone accounting for US $\$ 9.7$ billion damage to infrastructure, farms, homes and other direct and indirect losses. Of extensive disaster losses, defined as low severity losses associated with high-frequency events, 97\% are weather-related. While mortality is usually low these disasters are responsible for major damage to local infrastructure, housing and livelihoods of low-income households and communities. The damage associated with highly localized flooding, landslides, fires and storms in low- and middle-income countries impacts on economic growth. For example, since the 1990s, the number of houses destroyed relative to population growth in 21 countries has increased six-fold, far faster than the economic loss caused by major hazards. The downstream impacts of extensive disasters on health, education, structural poverty and displacement go unaccounted for in most countries, thus masking the real costs of disaster. ${ }^{65}$ Disasters also lead to largescale internal displacement, with the Pakistan floods leaving 6 million people in need of shelter. ${ }^{66}$

The Report finds that, globally, drought risk is a hidden disaster risk with impacts on agriculture affecting other economic sectors but that it is poorly understood and badly managed. Only a few countries document drought losses or have a national policy to address the risks even though recent droughts saw agricultural yields reduced by $20-40 \%$ in the Caribbean, losses of US $\$ 2.34$ billion in Australia and $75 \%$ of farmers suffering total crop failure in the Syrian Arab Republic in one season. ${ }^{67}$ The Report notes that along with other factors such as poverty and vulnerability, decreasing rainfall, climate variability and climate change are key factors for drought risk. ${ }^{68}$

The financial exposure that governments face from extensive disasters is staggering. Calculations for disaster loss in Colombia show that to address losses in publicly owned assets as well as uninsured private assets of low-income groups, cost ranges from US\$100 000 some 100 times per year, to US\$1 billion at least once every 30 years. In Mexico (excluding impacts from droughts) the government is likely to incur weather-related disaster losses of more than US\$1 million at least 50 times a year and more than US\$1 billion at least once every 6 years. The government in Nepal will need to make good losses amounting to US\$1 million 10 times each year amounting to US\$100 million every second year. ${ }^{69}$ It is no surprise that in reality, as the Report notes, few governments meet their responsibilities for covering substantial losses and these are usually transferred to and borne by low-income households. ${ }^{70}$

In May 2011, the Global Platform for Disaster Risk Reduction reported at its bi-annual conference ${ }^{71}$ that disaster-related losses are increasing across all regions, threatening the economies of low- and middle-income nations as well as outpacing wealth gains across many of the world's more affluent nations. Disasters happen because development patterns are not adjusting to more frequent and extreme catastrophes

65. Ibid., at 4.

66. Ibid., at 5 .

67. Idem.

68. Ibid., at 6 .

69. Ibid., at 8 .

70. Ibid., at 8 .

71. See <http://www.unisdr.org/archive/19873> accessed 19 June 2011. 
and emerging risks such as climate change, rapid urbanization, and risks associated with insufficient disaster management and planning. At the conference, major insurers $^{72}$ called on the industry to assist government with analysing the root causes of non-resilient activity; encouraging the private sector to share its expertise in construction, communications, financing, transport and contingency planning; sharing knowledge about risk prediction, forecasting and early warning; conducting risk assessments; and helping establish standards and procedures to enhance resilience. Insurers' interest in this area is obvious, given that in 2010-2011, the payout for global catastrophes was US $\$ 37$ billion. $^{73}$

\section{THE WAY FORWARD: TOWARDS A GLOBAL JUSTICE VISION AND AWAY FROM PAROCHIAL VESTED INTERESTS}

This article has provided an informational base in order to call for a process of 'practical reasoning' and for a move away from 'positional illusions and sequestering' about climate change so as to call for appropriate international and domestic responses in the interest of global climate justice. The local preconceptions and prejudices which have so dominated the climate change debate surely cannot survive reasoned confrontation with information not restricted by the same parochialism. ${ }^{74}$

The author argues that the failure of the international community to respond adequately to an issue which it itself regards as 'one of the greatest challenges of our time' might be regarded as 'unreason'. The prevalence and resilience of 'unreason' must be confronted by better reasoning. Sen has stated that 'unreason is mostly not the practice of doing without reasoning altogether, but of relying on very primitive and very defective reasoning'. ${ }^{75}$ What matters most in the context of climate change is the examination of what reasoning would demand in the pursuit of justice ${ }^{76}$ and the recognition that positional illusions can impose serious barriers to broadening the informational basis of evaluations. This is one of the reasons why perspectives about the threat of climate change from elsewhere, including from far away, have to be systematically invoked. ${ }^{77}$

Sen explains why, in Western fossil fuel democracies like the US, Canada and Australia, a state of 'unreason' might predominate, and links this directly to the philosophical tradition of 'social contract' theory which underpins democracy in these countries. Central to Sen's idea of justice is a rejection of the Rawlsian focus on 'transcendental institutionalism' as a path to justice and a preference for Adam Smith's invocation of the impartial spectator, as well as for the modern social choice theory of Kenneth Arrow in the mid-twentieth century. ${ }^{78}$ In explaining this, Sen compares the two major traditions which have emerged in Western philosophical discourse, although he is careful to explain that his Idea of Justice draws on both

72. These include WillisRe, Credit Suisse, Titan America, Cisco Internet Business Solutions Groups and MunichRe Foundation.

73. E Johnston, 'Global Disasters Take Toll on Local Insurers', Sydney Morning Herald, 24 March 2011.

74. Sen, above n 10 , vii.

75. Ibid., at xix.

76. Idem.

77. Ibid., at 169 .

78. Ibid., at xvi. 
the intellectual discontent expressed during the European enlightenment and by nonWestern societies, particularly in Indian intellectual history. ${ }^{79}$

The first major tradition in Western philosophical discourse is social contract theory, espoused by philosophers such as Hobbes, Locke, Rousseau, Kant and, particularly for current purposes, by the work of John Rawls. The second is what Sen describes as the comparative approach, represented in the work of philosophers such as Smith, Condorcet, Wollstonecraft, Bentham, Marx, John Stuart Mill and, in the mid-twentieth century, by Kenneth Arrow. ${ }^{80}$ While an area of commonality between the contractarian and comparative traditions lies in their mutual reliance on reasoning and in their mutual invocation of the demands of public discussion, ${ }^{81}$ they deploy divergent lines of reasoning about justice. Social contract theory tends to concentrate on identifying just institutional arrangements for society, which Sen refers to as 'transcendental institutionalism'. It concentrates on what the contractarian tradition identifies as 'perfect justice' and in searching for that perfection, concentrates on getting the institutions right, while proposing that the active presence of certain organizational arrangements would indicate that justice is being done. ${ }^{82}$

Sen aligns himself, in this respect, more closely with the comparative approach, which focuses on the actual lives of those most likely to suffer, both now and in the future. Essentially, Sen is arguing that the importance of human lives, experiences and realizations cannot be supplanted by information about institutions that exist and the rules that operate. While these are important, they are only part of the actual world and realized actuality goes well beyond the organizational picture. Actuality includes the lives that people manage or do not manage to live, which in light of the predicted impacts of climate change on developing countries discussed above, makes Sen's work highly relevant to a vision for climate change justice. ${ }^{83}$ Sen claims that his departure from the contractarian theory of justice has a direct bearing on political and moral philosophy, and may also have pertinence for debates and decisions on practical policies and programmes ${ }^{84}$ The author agrees that Sen's work can be highly relevant in applied areas, such as climate change regulation. Most importantly, his rejection of contractarian theory has many far-reaching implications for the nature and reach of the idea of justice. ${ }^{85}$

Sen's dissatisfaction with the Rawlsian approach concerns his argument that the focus on setting up 'just institutions' inescapably limits the involvement of participants in the pursuit of justice exclusively to members of the nation state. Yet what happens in any particular country cannot but have effects, and sometimes enormous consequences, for the rest of the world. Each country may have parochial beliefs that call for more global examination and scrutiny, or for globally sensitive questioning. ${ }^{86}$ Furthermore, Rawls's presumption that people would abandon any narrow pursuit of self-interest once the social contract has been arrived at does not translate well into guidance about 'justice in the world [in which] we live rather than in the imagined

\footnotetext{
79. Ibid., at xiii.

80. Ibid., at xvi.

81. Ibid., at xvii.

82. Ibid., at 10 .

83. Ibid., at 18.

84. Ibid., at xi.

85. Ibid., at viii.

86. Ibid., at 71 .
} 
world with which Rawls is primarily concerned' ${ }^{87}$ For Sen, impartial scrutiny is an integral part of justice, while 'bringing reasoning to the world becomes the enterprise of morality rather than metaphysics and the work as well as the hope of humanity'. ${ }^{8}$

The author finds Sen's theory of justice, which aims at guiding practical reasoning and impartial scrutiny about what should be done, compelling in the context of climate change. ${ }^{89}$ Sen is not concerned that by engaging in reasoned argument with oneself and others competing priorities may survive despite the confrontation of reason. Reasoned scrutiny cannot remove the risk of plurality or ensure that the answer will be correct, but it insists that public discussion be as objective as it reasonably can be. ${ }^{90}$ After all, impartiality is an integral part of justice. ${ }^{91}$

Can the failure of nation states to commit to significant emissions reductions be partly due to the neglect of the interests and perspectives of precisely those who are not parties to the social contract of a polity, but who bear most of the consequences of the decisions taken in the particular polity $?^{92}$ As Sen recognizes, liberation from positional sequestering, for example on climate change, may not always be easy but it is a challenge that has to be met for the sake of ethical, political and legal thinking. ${ }^{93}$ Moreover, there is a long history of attempts to go beyond the positional confinement of our moral concerns to the proximate 'neighbourhood', ${ }^{94}$ and a deep fragility in the intellectual basis of thinking of people in terms of fixed communities of neighbours. ${ }^{95}$ An understanding of justice, particularly in the contemporary world, must acknowledge that the neighbourhood is constructed by our relations with distant people. In truth, with climate change ' $[t]$ here are few non-neighbours left in the world today'. ${ }^{96}$

\section{A COMPETING LAW AND ECONOMICS VIEW OF CLIMATE JUSTICE}

It is interesting at this juncture to compare Sen's approach to justice, relied upon here to develop an approach to climate change justice, with that of Posner and Weisbach in Climate Change Justice ${ }^{97}$ given that one can regard all of their work as emanating from a welfarist tradition. Posner and Weisbach allow national, or local, preferences to dictate the parameters of a climate change treaty and offer a vision of climate change justice which is so at odds with that developed by the author that many of their essential precepts can be challenged, although it would be impossible to do so comprehensively in this article. However, the central thesis of their work is that there is no obligation to approach climate change justice through a climate treaty which places emissions reduction targets on developed economies. ${ }^{98}$ Moreover, the

87. Ibid., at 79 .

88. Ibid., at xvii.

89. Ibid., at 42 .

90. Ibid., at 40.

91. Ibid., at 42.

92. Ibid., at 140 .

93. Ibid., at 155 .

94. Ibid., at 170 .

95. Ibid., at 171 .

96. Ibid., at 173 .

97. Posner and Weisbach, above n 12.

98. Ibid., at 455 . 
authors adopt an almost exclusively anthropocentric view of a climate change treaty and assert repeatedly that '[a] climate treaty is not the only method of redistributing wealth and is unlikely to be the best way'. ${ }^{99}$ In so doing, they appear to downplay the essential objective of the UNFCCC, which is to 'prevent dangerous anthropogenic interference with the climate system' by stabilizing atmospheric concentrations of greenhouse gases 'within a time frame sufficient to allow ecosystems to adapt naturally to climate change, to ensure that food production is not threatened and to enable economic development to proceed in a sustainable manner'. ${ }^{100}$ Essentially, the authors reject an approach to allocating responsibility for climate change based on corrective justice, distributive justice and per capita emissions.

\subsection{Rejecting a corrective justice approach to climate justice}

In rejecting a corrective justice approach, the authors necessarily also reject Sen's call for an approach to justice which gazes beyond the border. Essentially, the authors claim that any climate treaty must satisfy International Paretianism. Here, all states must believe themselves better off 'by their lights' as a result of the climate treaty 'since history provides few cases where states act against their own perceived interest in order to satisfy the moral claims of other states'. ${ }^{101}$ The authors go further to state that, in some instances, rich countries might not be quite so badly affected by climate change as poor countries and so if they do commit to drastic emissions reductions on behalf of poor countries that are affected badly, they might be entitled to 'side payments' from those poor countries for their efforts. They argue, in addition, that a corrective justice vision of climate change justice is backward looking and focuses on historical emissions; ${ }^{102}$ punishes individuals; and cannot be applied to nation states. Such an approach would 'force many people who have not acted wrongfully to provide a remedy to many people who have not been victimized'. ${ }^{103}$

While it is true that the requirement that developed countries should take action before developing countries continues to permeate international negotiations, this is consistent with a well established principle of International Law - the principle of common but differentiated responsibility. This principle is not unique to climate treaties. Nor is it merely backward looking or based solely on notions of corrective justice. While the principle recognizes historical responsibility, it also looks to the future in 2020 and 2050 to allocate the remaining carbon budget primarily in accordance with the right to development. This is an enduring right protected by International Environmental Law as is recognized in the Rio Declaration on Environment and Development. ${ }^{104}$ These instruments declare a vision for the future and cannot be wished away by those who seek to deconstruct their tenets. The principle of common but differentiated responsibility is also firmly grounded in the notion of feasibility that the authors so value throughout the text. When the world is confronted by an

99. Ibid., at 5.

100. UNFCCC Art. 2.

101. Posner and Weisbach, above n 12 at 6.

102. Ibid., at 102 .

103. Ibid., at 104 .

104. Principle 3 of the Rio Declaration asserts ' $[\mathrm{t}]$ he right to development must be fulfilled so as to equitably meet developmental and environmental needs of present and future generations'; available at <http://www.unep.org/Documents.Multilingual/Default.asp?documentid=78\& articleid=1163> accessed 4 July 2011. 
emerging threat such as global climate change, those developed economies, like the US, that are best equipped both financially and technologically to respond ought to do so, while developing economies should do so in accordance with their capabilities.

The authors seek to individualize the issue of moral responsibility for emissions without ever mentioning that placing a price on carbon pollution through international treaties is aimed ultimately at the most significant polluting industries within individual jurisdictions. For example, they question why Americans alive today should pay for the stock of greenhouse gases emitted into the atmosphere before they were born and before people understood the problem of climate change. ${ }^{105}$ Here the authors dispute the application of Gardiner's moral claim. Yet in jurisdictions where an emissions trading scheme or carbon tax is established to price these emissions, the regulation targets polluters not individuals. The moral responsibility of polluters is clear. They have known for at least two decades about the consequences of their activities for global climate change and done nothing. While it is true that individuals are impacted by an impost on the price of electricity and other fossil fuels, compensation packages are offered to those least able to pay. The authors seem blind also to the moral responsibility of current generations living within the most developed economies, including America and Australia, to curtail their lifestyles which impose enormous ecological footprints on the planet, including through being the largest per capita emitters. ${ }^{106}$

Posner and Weisbach find the idea that nation states can be moral agents 'highly unappealing', as notions of collective responsibility have been rejected by mainstream philosophers, as well as by institutions such as criminal and tort law. Yet, it is highly consistent with the moral imperatives of International Environmental Law for nation states to assume legal responsibility for regulating behaviour within their jurisdictions. In a sense, nation states are simply proxies for those within their borders who have degraded, and continue to degrade, the environment. Nation states assume the burden of regulation on behalf of the global community once the risks of certain activities become clear. One of the most recent and relevant examples is the Montreal Protocol on Substances that Deplete the Ozone Layer where, based on their historic responsibility, developed countries assumed obligations early, while developing countries were given a period of grace to match the commitments of the developed countries. In the area of World Trade Law, nation states are the proxies of their corporations which insist on the right to operate in foreign jurisdictions.

The authors base their objections to the principle of common but differentiated responsibility for climate change principally on the Kyoto Protocol. However, as will be discussed below, under the Cancun Agreements, developing countries have all made commitments to reduce emissions within their respective capabilities and have agreed to international monitoring, reporting and verification where their Nationally Appropriate Mitigation Actions (NAMAs) are internationally funded. While there is obviously some truth in Posner and Weisbach's claim that until developing countries like China assume full legal responsibility to meet emission reduction targets, developed countries will 'drag their feet', climate science will inevitably strengthen the case for all parties to move towards a legally binding climate change treaty.

105. Posner and Weisbach, above n 12 at 113 . Here Posner and Weisbach state that $54.5 \%$ of Americans were born after 1975 and are not responsible for half of the emissions that occurred prior to this time and that $27 \%$ of Americans are younger than 20 years old and are not responsible at all for these emissions.

106. See also Farber on this point, above n 13 at 14. 
Yet developed economies should not escape their duty to go first and to demonstrate leadership and moral authority in so doing. Indeed, as Farber has noted, '[t]he injustice of causing harm to the poorest countries and to future generations provides powerful arguments for stringent limitations on emissions' and 'cash compensation for possible catastrophic harm may not be adequate even if feasible'. ${ }^{107}$ Finally, there are clear examples where nation states have been found morally responsible for compensation payments, as witnessed by Articles 231-247 of the Treaty of Versailles, the Iran-US Claims Tribunal established in 1981 under the Algiers Accords. Currently, the European Convention on Human Rights ${ }^{108}$ requires nation states to compensate those whose protected rights have been infringed. ${ }^{109}$

The final issue with regard to corrective justice is whether the US has any culpability giving rise to moral responsibility to commit to legally binding emissions reductions. Posner and Weisbach assert that intentional, reckless or negligent action is usually thought to be required for a corrective justice claim. ${ }^{110}$ They conclude that the claim that US policy has been negligent is far-fetched. ${ }^{111}$ How so, one wonders? It is a legal fact that the reason the 1997 Kyoto Protocol could only enter into force in 2005 is that with the US refusing to ratify the Protocol the provisions of Article 25 were only satisfied upon Russia's ratification. ${ }^{112}$ Also, the US's withdrawal resulted, in large part, in Australia's refusal to ratify and in the two leaders, George Bush and John Howard, attempting deliberately to undermine multilateral negotiations on climate change. So much is evidenced by their establishment of the US-Australia Climate Change Partnership, Asia Pacific Partnership on Clean Development and Climate, ${ }^{113}$ and George Bush's announcement in June 2007, of his intention to establish a New International Framework on Climate Change. Here, the US would work with other countries to establish a new international framework to address global climate change once the Kyoto Protocol expired in 2012. ${ }^{114}$ There was speculation at the time that the then Australian Prime Minister, John Howard, would use the September 2007 Asia Pacific Economic Co-operation (APEC) summit to try to forge an international consensus on climate change designed to bring China, India and the US into global efforts to cut greenhouse gas emissions ${ }^{115}$ building on the Asia-Pacific Partnership on Clean Development and Climate. ${ }^{116}$ China made it clear at the APEC meeting that multilateral negotiations under the Kyoto Protocol

107. Ibid., at 26.

108. Available at <http://www.echr.coe.int/NR/rdonlyres/D5CC24A7-DC13-4318-B4575C9014916D7A/0/ENG_CONV.pdf> accessed 4 July 2011.

109. Ibid., Art. 13.

110. Posner and Weisbach, above n 12 at 110.

111. Ibid., at 113 .

112. Art. 25 provides that ' $[\mathrm{t}]$ his Protocol shall enter into force on the ninetieth day after the date on which not less than 55 Parties to the Convention, incorporating Parties included in Annex I which accounted in total for at least 55 per cent of the total carbon dioxide emissions for 1990 of the Parties included in Annex I, have deposited their instruments of ratification, acceptance, approval or accession.'

113. See <http://www.asiapacificpartnership.org/english/default.aspx> accessed 5 July 2011.

114. Available at $<\mathrm{http}: / /$ usinfo.state.gov/xarchives/display.html?p=texttrans-english\&y= 2007\&m=May\&x=20070531155142eaifas0.1002161 > accessed 10 June 2007.

115. Sydney Morning Herald, 7 June 2007.

116. Office of the Prime Minister, 28 July 2005 and the Australia Institute, 28 July 2005 available at <http://www.pm.gov.au/news/media_releases/media_Release1482.html $>$ accessed 16 October 2005. 
were the only way forward and this was confirmed in the Sydney APEC Leaders' Declaration on Climate Change, Energy Security and Clean Development. ${ }^{117}$ Canada has also relied on US non-ratification to withdraw from the Kyoto Protocol in 2011.

Finally, in December 2007, the United States House of Representatives Committee on Oversight and Government Reform, based on 27000 pages of documents from the White House Council on Environmental Quality and the Commerce Department, stated, '[t]he evidence before the Committee leads to one inescapable conclusion: the Bush Administration has engaged in a systematic effort to manipulate climate change science and mislead policymakers about the dangers of global warming ... The Bush Administration has acted as if the oil industry's communications plan were its mission statement'. It was also the Environmental Protection Agency (EPA) under the Bush Administration which refused to regulate vehicular GHG emissions, preferring to rely on the President's 'comprehensive plan' on climate change, while under an Obama Administration it has been active in regulating these emissions from a range of sources under the Clean Air Act. ${ }^{118}$

The Bush years, at the very least, resulted in years of inaction on climate change in the US and significantly undermined multilateral negotiations and progress on climate change at a critical time. The inability of Obama to secure Congressional authority to ratify the Kyoto Protocol simply compounds the problem for international negotiations. In the author's view the US's culpability and the establishment of causation, required by Posner and Weisbach, ${ }^{119}$ are well established.

\subsection{Rejecting the distributive justice approach to climate justice}

While Posner and Weisbach see a distributive approach to climate change as being 'powerfully salient', ${ }^{120}$ their ultimate rejection of such an approach is based on a rejection of the common but differentiated principle. They regard the principle as resulting in a massive, and unjustified, distribution of wealth from rich to poor countries. This is of deep concern for the fact that it, either mistakenly or deliberately,

117. See <http://www.smh.com.au/news/apec/sydney-declaration-on-climate-change-andenergy/2007/09/09/1189276526002.html> accessed 5 July 2007.

118. In Massachusetts v EPA 549 U.S. 497 (2007), 12 states led by Massachusetts challenged the EPA's refusal to regulate GHG emissions from vehicles. The question before the court was whether the EPA has statutory power to regulate these emissions under section 202(a)(1) of the Clean Air Act. The United States Supreme Court held that the harms associated with climate change are serious and well recognized. The Court found that GHGs fit well within the definition of 'air pollutants' and that the EPA has statutory authority to regulate such emissions from motor-vehicles. Since then the EPA has promulgated the 2009 Mandatory Greenhouse Gas Reporting Regulation available at <http://www.epa.gov/climatechange/emissions/downloads09/ GHG-MRR-FinalRule.pdf $>$ accessed 28 June 2012; the 2010 National Renewable Fuel Standard available at <http://www.epa.gov/OMS/renewablefuels/420f10007.pdf> accessed 10 September 2010; the Final Rule to establish a National Program consisting of new standards for lightduty vehicles that will reduce greenhouse gas emissions and improve fuel economy available at Federal Register / Vol. 75, No. 88 / Friday, May 7, 2010 / Rules and Regulations p. 25324 (accessed 28 June 2012); the Prevention of Significant Deterioration and Title V Greenhouse Gas Tailoring Rule; Final Rule regulating GHG emissions from stationary sources available at 40 CFR Parts 51, 52, 70, et al (accessed 28 June 2012).

119. Posner and Weisbach, above n 12 at 104.

120. Schlosberg, above n 14 at 455. 
reduces the tenets of the UNFCCC, ad absurdum, largely to economic ones, where rich countries should reject the idea that they are obliged to reduce the likelihood of harm solely because they are rich. ${ }^{121}$ Their objections to the common but differentiated principle have already been addressed above. They go on, curiously, to assert that reducing carbon emissions is not a way to help today's poor and that if costs are incurred to reduce emissions, these resources are not available to help today's poor. Further, poor nations may be better off if the resources that would be dedicated toward abatement are used in other ways, and in any case, the future poor will be less-poor. ${ }^{122}$ They claim that 'development aid is likely to be more effective than greenhouse gas restrictions as a method of helping poor people in poor nations'. ${ }^{123}$

The authors go on to say that if distribution from rich nations to poor nations is generally desirable, it is not at all clear why the US should join an agreement that is not in its interest. Can the authors really be arguing that the US could evade its responsibility to drastically reduce emissions by making cash payments to the poor right now? It would seem so, especially given that, in their view, the future 'less-poor' are less in need, or less deserving, of the US's abatement efforts today. How is this consistent with the purpose of the UNFCCC, supported by climate science, which is to save the planet, all of its ecosystems and species, and all of human society from catastrophe? The authors' approach represents a reductionist view of a climate treaty principally as being a vehicle for redistributing money from the rich to today's poor.

Adopting a state-centrist position, Posner and Weisbach prefer an alternative 'efficient', 'feasible' and 'welfarist' climate treaty which is two treaties in one - a climate treaty incorporating distributive side payments, and a foreign aid treaty. ${ }^{124}$ According to the authors, International Paretianism requires that all states that participate in the climate treaty must be economically better off, or at least not much worse off, in the sense that their abatement costs cannot be significantly more than the benefits gained in the form of avoided climate-related harms. ${ }^{125}$ Farber has questioned whether the requisite economic analysis proposed by Posner and Weisbach is possible, given that climate change is a prime example of a problem with large downside risks that are not well understood. ${ }^{126}$ Add to this the authors' view that if the US or China were to agree to reduce its emissions when they might not be particularly affected by climate change, they might be entitled to side payments from those poor countries most affected by climate change. ${ }^{127}$ The US or China might, however, forego this entitlement in the interest of foreign aid. Having so strongly advocated cash payments to the current poor rather than a distributive climate treaty, the authors nevertheless express their strong reservations that such payments will assist the poor given the level of corruption in developing countries. ${ }^{128}$ This has been described as "the tired criticism' that it is poor governments of the South that are corrupt and cannot be trusted to spend international aid properly. ${ }^{129}$ One wonders whether the governance

121. Posner and Weisbach, above n 12 at 79.

122. Ibid., at 27.

123. Ibid., at 78 .

124. Ibid., at 85 .

125. Ibid., at 179 .

126. Farber, above n 13 at 21.

127. Posner and Weisbach, above n 12 at 86.

128. Ibid., at 90.

129. Schlosberg, above n 14 at 457 . 
arrangements for the Green Climate Fund under the Cancun Agreements, discussed below, allay any of these concerns.

\section{7 'UNREASON', 'POSITIONAL ILLUSIONS' AND THE FUTURE OF INTERNATIONAL NEGOTIATIONS UNDER THE UNFCCC}

Having chosen to rely on Sen's view of justice rather than on Posner and Weisbach's in crafting a global justice vision for climate law, the author concludes by analysing the current status of international negotiations under the UNFCCC. This analysis shows that the negotiations are a consequence of the Parties' 'unreason' and 'positional illusions and sequestering', both of which are imposing serious barriers to meaningful progress.

\subsection{The post-2012 framework}

Preparations for the post-2012 climate change regime commenced in 2007 at COP 13 resulting in the Bali Action Plan. ${ }^{130}$ Since then, the most significant negotiations have been the 2009 COP 15 at Copenhagen, the 2010 COP 16 at Cancun and the 2011 COP 17 at Durban. Since 2007, the negotiations have proceeded along the two track process established under the Bali Action Plan which comprises the Ad Hoc Working Group on Long-term Cooperative Action under the Convention (AWGLCA) and the Ad Hoc Working Group on Further Commitments for Annex I Parties under the Kyoto Protocol (AWG-KP). These two working groups were established to delay a decision on whether future legally binding GHG reduction commitments would be made under the Kyoto Protocol. The working groups have met quarterly to further negotiations since Bali. At COP 17 it was decided that the AWG-LCA's mandate would be extended for only one more year, after which it would be terminated.

The 2010 COP 16 negotiations concluded in the Cancun Agreements ${ }^{131}$ which essentially confirmed the parameters of the 2009 Copenhagen Accord, ${ }^{132}$ under which developed and developing countries have made voluntary emissions reduction commitments. The AWG-LCA text ${ }^{133}$ emerging from COP 17 builds on agreements

130. FCCC/CP/2007/6/Add.1* available at <http://unfccc.int/resource/docs/2007/cop13/eng/ 06a01.pdf> accessed 28 June 2012.

131. See The Cancun Agreements: 2010 Outcome of the work of the Ad Hoc Working Group on Long-term Cooperative Action under the Convention, Decision 1/CP.16 available at $<$ http:// unfccc.int/resource/docs/2010/cop16/eng/07a01.pdf\#page=2> accessed 29 June 2011; The Cancun Agreements: Outcome of the work of the Ad Hoc Working Group on Further Commitments for Annex I Parties under the Kyoto Protocol at its fifteenth session, Decision 1/CMP.6 available at $<$ http://unfccc.int/resource/docs/2010/cmp6/eng/12a01.pdf\#page $=3>$ accessed 29 June 2011; and The Cancun Agreements: Land use, land-use change and forestry, Decision 2/CMP.6 available at <http://unfccc.int/resource/docs/2010/cmp6/eng/12a01.pdf\#page=5> accessed 29 June 2011.

132. FCCC/CP/2009/11/Add.1, 30 March 2010, available at <http://unfecc.int/resource/docs/ 2009/cop15/eng/11a01.pdf> accessed 29 June 2011.

133. See 2011 Outcome of the Work of the Ad Hoc Working Group on Long-term Cooperative Action under the Convention available at $<\mathrm{http}$ ///unfccc.int/files/meetings/durban_nov_2011/ decisions/application/pdf/cop17_lcaoutcome.pdf > accessed 13 December 2011. 
reached at COP 16. The key elements of the AWG-LCA's deliberations include a shared vision for long-term cooperative action; decisions on enhanced action on adaptation; enhanced action on mitigation; ${ }^{134}$ finance, technology and capacity building; and review of the long-term global goal. COP 16 affirmed that climate change is one of the greatest challenges of our time ${ }^{135}$ and that scaled-up overall mitigation efforts allowing for the achievement of desired stabilization levels ${ }^{136}$ and for deep cuts in GHG emissions ${ }^{137}$ are necessary. COP 16 and 17 both recognized the need to hold the increase in global average temperatures to below $2^{\circ} \mathrm{C}$ above pre-industrial levels, as well as the need to consider strengthening the long-term goal in relation to a global average temperature rise of $1.5^{\circ} \mathrm{C}$ on the basis of the best available scientific knowledge. ${ }^{138}$ At both COP 16 and COP 17, Parties agreed that they should cooperate in achieving the peaking of GHG emissions as soon as possible. ${ }^{139}$ COP 16 decided that in all climate change-related actions, human rights should be fully respected. ${ }^{140}$ The COPs also took note of the collective commitment by developed countries to provide US $\$ 30$ billion in fast-start funding for the period $2010-2012 .{ }^{141}$ With regard to longer term finance, developed countries will commit US\$100 billion per year by 2020 to address these needs, ${ }^{142}$ with the funds coming from public and private, bilateral and multilateral and alternative sources. ${ }^{143}$ A significant share of new multilateral funding for adaptation should flow through the Green Climate Fund, ${ }^{144}$ which will be designated as an operating entity of the financial mechanism of the Convention. ${ }^{145}$

A decision on the future of the Kyoto Protocol was made at COP 17. A decision was taken under the auspices of the AWG-KP ${ }^{146}$ that a second commitment period of the Protocol will begin on 1 January 2013 and end either on 31 December 2017 or 31 December 2020, to be decided by the AWG-KP in December $2012 .{ }^{147}$ It was

134. To view developed countries' commitments see <http://unfccc.int/resource/docs/2011/sb/ eng/inf01r01.pdf $>$ accessed 28 June 2012 and to view developing countries' Nationally Appropriate Mitigation Actions see <http://unfccc.int/resource/docs/2011/awglca14/eng/inf01.pdf> accessed 28 June 2012.

135. Above n 127 Art. 1.

136. Ibid., Art. 2(a).

137. Ibid., Art. 4.

138. Ibid., Art. 4. See also Establishment of an Ad Hoc Working Group on the Durban Platform for Enhanced Action FCCC/CP/2011/L.X available at http://unfccc.int/files/meetings/ durban_nov_2011/decisions/application/pdf/cop17_durbanplatform.pdf (accessed 13 December 2011).

139. 2010 Outcome of the work of the Ad Hoc Working Group on Long-term Cooperative Action under the Convention Art 6. See also 2011 Outcome of the Ad Hoc Working Group on Long-term Cooperative Action under the Convention Art. 2.

140. 2010 Outcome of the work of the Ad Hoc Working Group on Long-term Cooperative Action under the Convention Art. 7.

141. Above n 127 Art. 95.

142. Ibid., Art. 98.

143. Ibid., Art. 99.

144. Ibid., Art. 100.

145. Ibid., Art. 102.

146. See 2011 Outcome of the work of the Ad Hoc Working Group on Further Commitments for Annex I Parties under the Kyoto Protocol at its sixteenth session available at <http://unfccc. int/files/meetings/durban_nov_2011/decisions/application/pdf/awgkp_outcome.pdf> accessed 13 December 2011.

147. Ibid., Art. 1. 
decided at COP 17 that a new body, the Ad Hoc Working Group on the Durban Platform for Enhanced Action, ${ }^{148}$ will be established, noting with 'grave concern' that the significant gap between the Parties' current mitigation pledges by 2020 means that it is unlikely that the increase in global average temperatures will be held below $2{ }^{\circ} \mathrm{C}$, or below $1.5^{\circ} \mathrm{C} .{ }^{149}$ This Working Group started its work as a matter of urgency in the second quarter of 2012 and must complete its work no later than 2015 'to adopt a Protocol, or other legal instrument or an agreed outcome with legal force under the UNFCCC'. The Protocol must be adopted at COP 21 in 2015 and come into effect from 2020. The process must raise the level of ambition of all Parties, including all developed and developing countries, and must be informed by the IPCC's Fifth Assessment Report and the outcomes of the progress review to be conducted between 2013-2015. ${ }^{150}$ A workplan will be launched to close the ambition gap to ensure the highest possible mitigation efforts by all Parties.

In short, there is an in-principle agreement that the Kyoto Protocol will enjoy a second commitment period, although a final decision will only be made on this at COP 18 in December 2012. Beyond that, the Durban Platform is mandated to achieve consensus on a new agreement the legal status of which has yet to be determined, and which will only come into effect in 2020. Meanwhile, GHG emissions continue to climb on an upwards trajectory to a possible $3.2^{\circ} \mathrm{C}$ temperature rise. ${ }^{151} \mathrm{How}$, one might ask, can the past five years of negotiations have delivered such ephemeral outcomes, which manifest such pronounced 'unreason'? What is absolutely clear, despite Posner and Weisbach's objections, is that the negotiations continue to proceed 'on the basis of equity and in accordance with common but differentiated responsibilities and respective capabilities'. ${ }^{152}$ Given their stated objections to this principle, the US and Canada will not agree to be legally bound to reduce their emissions unless China, and possibly other large developing countries, such as Brazil and India, agree to do likewise. Yet these developing countries, consistently with the principle, refuse to contemplate legally binding commitments until developed countries have agreed to be legally bound to drastic emissions reductions targets. Even the European Union and Australia have made conditional voluntary commitments which could be strengthened if the international community agrees to significant reductions. ${ }^{153}$ So the Parties continue to play a dangerous game of 'chicken'. Or, as Sen would have it, the Parties allow their 'positional illusions' to confine their moral concerns to the proximate 'neighbourhood' 154 and to restrict their thinking to fixed communities of neighbours ${ }^{155}$ rather than making the commitments needed to ward off the worst effects of climate change on the planet.

Perhaps it is time to peer behind the veil of international 'positioning' to consider the national emissions reductions strategies being adopted by the large emitters. Here one finds a Democrat US Congress which, between 2009-2010, failed to enact

148. See Establishment of an Ad Hoc Working Group on the Durban Platform for Enhanced Action available at $<$ http://unfccc.int/files/meetings/durban_nov_2011/decisions/application/ pdf/cop17_durbanplatform.pdf > accessed 13 December 2011.

149. Ibid., Preamble.

150. Ibid., Art. 6.

151. See Rogel, above $\mathrm{n} 6$.

152. 2011 Outcome above n 130 Art. 1.

153. See above n 134.

154. Sen, above $\mathrm{n} 10$ at 170 .

155. Ibid., at 171 . 
climate change legislation. ${ }^{156}$ Further, although the EPA has been active in regulating GHGs, ${ }^{157}$ (as have other agencies such as the Council on Environmental Quality (CEQ) $)^{158}$ and the National Highway Traffic Safety Authority) ${ }^{159}$ a Republican Congress currently has before it numerous House and Senate Bills ${ }^{160}$ blocking any regulation of GHGs, repealing all existing measures, including the Energy Independence and Security Act of 2007, and denying funding to the EPA and CEQ for climate regulatory activities.

By distinction, in August 2010, China's National Development and Reform Commission (NDRC) selected five provinces and eight cities as Low Carbon Pilot Regions which must set emissions reduction targets and develop and implement low carbon strategies. ${ }^{161}$ Six pilot regions ${ }^{162}$ have also been identified for a pilot emissions trading scheme (ETS) to be operational by 2013. This is intended to lay the foundation for a national trading scheme by 2015. In 2010, China emerged as the world's clean energy superpower with installed renewable capacity of 103.36 GW compared with the US's $57.99 \mathrm{GW}$ and clean energy intensity investment per \$ GDP $0.55 \%$ compared with $0.33 \%$ in the US. ${ }^{163}$ In 2010 , China's lead over the US in financial new investment increased from US $\$ 22.3$ billion to US $\$ 23.8$ billion. ${ }^{164}$ China has a target of $15 \%$ non-fossil fuels in energy consumption by 2020 . In the US, there is no federal renewable energy target. ${ }^{165}$ China's $12^{\text {th }}$ Five Year Plan (2011-2015) contains the following carbon and energy targets against a 2010 baseline: increase to $11.4 \%$ the proportion of non-fossil fuels in the energy mix by 2015 ; reduce energy intensity by $16 \%$ by 2015 ; and reduce $\mathrm{CO}_{2}$ intensity by $17 \%$ by $2015 .{ }^{166} \mathrm{On}$ 20 April 2012, China's State Council adopted an industry development plan that sets

156. See US Clean Energy and Security Act 2009 (Waxman-Markey Bill), which passed the House of Representatives by 7 votes on 26 June 2009, and the The American Power Act (Kerry-Lieberman Bill) as introduced into Senate on 12 May 2010, and reintroduced, as amended, on 13 July 2010.

157. See above n 114 .

158. See 2010 Draft NEPA Guidance on the Consideration of Greenhouse Gases available at <http://www.whitehouse.gov/sites/default/files/microsites/ceq/20100218-nepa-considerationeffects-ghg-draft-guidance.pdf $>$ accessed 9 September 2010.

159. The EPA and National Highway Traffic Safety Administration (NHTSA) have jointly issued the GHG emission and fuel efficiency standard cited above n 133.

160. For a comprehensive summary of these developments see the Columbia Centre for Climate Change Law's legislation tracker available at <https://www.law.columbia.edu/centers/ climatechange/resources/legislation> accessed 27 June 2012.

161. See Pilot Carbon Trading in China (Climate Focus: November 2011) available at $<\mathrm{http}: / /$ www.climatefocus.com/documents/files/piloting_carbon_trading_in_china.pdf $>$ accessed 29 June 2012.

162. They are Beijing, Chongqing, Guandong, Hubei, Shanghai and Tianjin which overlap significantly with the Low Carbon Pilot Regions; ibid.

163. See Who's Winning the Clean Energy Race? (Pew Charitable Trust: 2010) at 12 available at <http://www.pewenvironment.org/uploadedFiles/PEG/Publications/Report/G-20ReportLOWRes-FINAL.pdf> accessed 29 June 2012.

164. See Global Investment in Renewable Energy Investment 2011 (Bloomberg New Energy Finance, London 2011) at 18 available at <http://www.unep.org/pdf/BNEF_global_trends_in_ renewable_energy_investment_2011_report.pdf> accessed 29 June 2012.

165. Ibid., at 28.

166. See 'China's Action on Climate Change' at <http://www.cleanenergyfuture.gov.au/chinasaction-on-climate-change/> accessed 29 June 2012. 
the target of an accumulative production and sales of 500000 pure electric and plug-in vehicles by 2015 , and more than 5 million by 2020 . It also aimed to lower the average fuel consumption of passenger cars produced in 2015 to 6.9 litres per 100 kilometres, and further to 5 litres per 100 kilometres in $2020 .^{167}$

On 2 May 2012, South Korea decided to adopt an ETS which will cap emissions at approximately $450 \mathrm{Mt}$ when the scheme launches in 2015 , declining to $350 \mathrm{Mt}$ in 2020. ${ }^{168}$ On 12 June 2012, Brazil's first ETS covering large emitters in Rio de Janeiro was announced, ${ }^{169}$ while on 19 April 2012, the Mexican Senate unanimously passed the General Law on Climate Change, which includes a requirement that Mexico reduce its carbon dioxide emissions by $30 \%$ below business-as-usual levels by 2020 and by $50 \%$ below 2000 levels by 2050 . It also mandates that $35 \%$ of the country's electricity should come from renewable sources by 2024 and requires mandatory emissions reporting by the country's largest polluters. ${ }^{170}$

The scenario that emerges behind the 'positional' posturing at the COPs is that developed countries like the US, Canada, and possibly Australia after the 2013 elections, ${ }^{171}$ are backpedalling on climate change programmes while developing countries begin to take them seriously. In the author's view, developing countries are now entirely justified in adhering to the common but differentiated principle. They are, ironically, taking the lead on climate change at the national level, while the US and Canada remain recalcitrant. ${ }^{172}$ There is no doubt that the global financial crisis unfolding in late 2008 has weakened the political appetite in these countries to impose yet another cost on their own struggling economies. Yet what is clear is that in these countries, and at times in Australia, the debate on climate change is sceptical, parochial and impoverished. Add to this the fact that influential politicians seem to lack either the knowledge, or the courage, to lead a 'reasoned discussion' on the issue. Citizens are encouraged to think only about the financial impost of carbon prices on themselves and their families, as politicians chase the goal of winning government in short-term election cycles. Seldom is the current scientific consensus on climate science clearly articulated and communicated. The potentially devastating impacts of climate change on all economies and ecosystems both now and in the future are rarely discussed. Instead, the most significant climate change messages are lost as political sound bites resonate in the voting public's consciousness. The voices of vested interests and 'unreason' need to be quietened and the perspectives of those from far away should be systematically invoked in the interests of climate justice.

167. See China Internet Information Service available at <http://www.china.org.cn/wap/201204/19/content_25183381.htm> accessed 29 June 2012 and for the original Chinese version see $<$ http://www.gov.cn/ldhd/2012-04/18/content_2116641.htm> accessed 29 June 2012.

168. See <http://www.pointcarbon.com/aboutus/pressroom/pressreleases/1.1889619> accessed 29 June 2012.

169. See <http://www.pointcarbon.com/aboutus/pressroom/pressreleases/1.1919247> accessed 29 June 2012.

170. See $<$ http://blogs.law.columbia.edu/climatechange/2012/05/07/mexicos-congress-passesclimate-change-bill/> accessed 29 June 2012.

171. Note that although a carbon price mechanism came into existence on 1 July 2012 in Australia, the leader of the Opposition, Tony Abbott, has vowed to abolish it on his first day in office if elected as Prime Minister.

172. The author is cognizant of the various state-based and regional climate change initiatives that have emerged in the US and Canada but chooses rather to focus on the lack of action by their national governments. 
The author is concerned that Posner and Weisbach's work, which by their own admission contains a limited view of morality, ${ }^{173}$ permits current generations in these countries to 'pass the climate change buck' to the next generation. Furthermore, their arguments may 'subvert our understanding of what is at stake"174 in the coming climate catastrophe, ${ }^{175}$ and so impede meaningful progress at subsequent UNFCCC negotiations.

At the same time, if major developing country emitters are prepared to take the domestic action on climate change as enumerated in this article, it must surely be a short step for them to negotiate in good faith under the Durban Platform for Action to adopt nationally appropriate legally binding emissions reduction targets, under the agreement proposed to be adopted in 2015.

Such progress, based on a global justice vision for climate law, is urgently needed if there is to be any hope of achieving, instead of radically disrupting, the globally agreed goals for sustainable development in 'The Future We Want'.

173. Posner and Weisbach, above n 12 at 6 .

174. Ibid., at 45.

175. See the title of J Hansen's book, above n 47. 